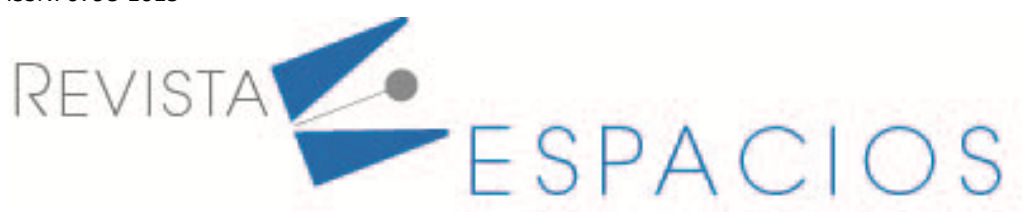

\title{
Organization of the process of developing students' media competence by means of information-educational environment
}

\section{Organización del proceso de desarrollo de la competencia mediática de los estudiantes mediante medio ambiente de información-educativo}

\author{
MILIUTINA, Anna A. ${ }^{1}$ \\ NIKITINA, Elena Y. ${ }^{2}$ \\ STERLIGOVA, Ekaterina A. ${ }^{3}$ \\ FORTYGINA, Svetlana N. ${ }^{4}$
}

\begin{abstract}
The article describes the experience of the South Ural State Humanitarian and Pedagogical University in assessing the development of media competence of students using the information-educational environment. Among the main research methods, an analysis of regulatory documents and an analysis of the results of a survey of respondents by ranking the components of media competence by degree of importance were used. The result of the research activity, the authors believe a theoretical understanding of the importance of media competence in the future professional activities of primary school teachers.

Keywords: media competence; education-information environment; elementary school teacher; technology of the information and communication.

\section{Resumen}

El artículo describe la experiencia de la Universidad Humanitaria y Pedagógica del Estado del Ural del Sur en la evaluación del desarrollo de la competencia mediática de los estudiantes que utilizan el entorno informativo educativo. Entre los principales métodos de investigación, se utilizó un análisis de documentos reglamentarios y un análisis de los resultados de una encuesta a los encuestados al clasificar los componentes de la competencia de los medios por grado de importancia. El resultado de la actividad de investigación, los autores creen una comprensión teórica de la importancia de la competencia de los medios en las futuras actividades profesionales de los maestros de primaria. Palabras clave: competencia mediática; ambiente de educación-información; profesor de escuela primaria; tecnologías de la información y la comunicación.
\end{abstract}

\footnotetext{
${ }^{1}$ Candidate of Pedagogical Sciences, Senior lecture,South Ural State Humanitarian Pedagogical University, Russian Federation, 69 Lenin prospect, 454080 , Chelyabinsk.miliutinaaa@cspu.ru

${ }^{2}$ Doctor of Pedagogical Sciences, Professor,South Ural State Humanitarian Pedagogical University, Russian Federation, 69 Lenin prospect, 454080, Chelyabinsk. nikitinaey@cspu.ru

${ }^{3}$ Assistant of the Department of English Philology,South Ural State Humanitarian Pedagogical University, Russian Federation, 69 Lenin prospect, 454080, Chelyabinsk. katerinasterligova13@gmail.com

${ }^{4}$ Candidate of Pedagogical Sciences, Associate Professor,South Ural State Humanitarian Pedagogical University, Russian Federation, 69 Lenin prospect, 454080, Chelyabinsk. fortyginasn@cspu.ru
} 


\section{Introduction}

In modern conditions of life, a person should be able to use various media in all fields of activity in order to remain a sought after professional. This is due to the fact that today society needs specialists who are able to rebuild their work activities in the virtual space mode. Competition in the framework of jobs is growing, so from the period of study in higher education institutions (universities) it is necessary to introduce work on the formation of media competence of the future professional in their field. After analyzing the work of Fedorov A.V., 2013; Zaznobina L.S., 1999; Chelysheva I.V., 2006; Usova Yu.N., 2010 and others, by media competence in this work we mean the presence of knowledge in the field of media, an adequate perception of media, and the ability to use them for the competent solution of tasks.

The modern legal and regulatory framework in the field of education presupposes that the teacher has a media competence formed at a certain level. The concept of "Digital School", "State Program of the Russian Federation "Information Society (2011-2020)"(approved by order of the Government of the Russian Federation of October 20, 2010 No. 1815-r)" involves working with the media in educational institutions. In addition, the National Project "Digital Economy" includes six federal projects: "Information Infrastructure", "Digital Technologies", "Digital Government Administration", "Normative Regulation of the Digital Environment", "Personnel for the Digital Economy" and "Information Security". Each of them to one degree or another reflects the need for any professional in his field to have elementary media competence.

If we consider today the role of media competence in the global education system, it is worth noting that countries are enriching with modern information technologies, the intensive development of distance learning forms, as well as the fundamentalization of education, one of the key components of which is orientation to the necessary and relevant knowledge necessary for a specialist in modern realities. In the framework of the Council of Europe (Council for cultural cooperation Council for cultural cooperation - CCC) and as part of the Council: Documentation Center for Education in Europe (Documetation center for education in Europe) among the main areas of activity in the field of education are indicated: the creation of information exchange networks and partnership country relations, research and practical advice for teachers and decision makers. Particular emphasis is placed on new forms of education, which could arise only with the help of new information technologies and communication technologies (loksha E. A., 2018). Thus, it is necessary to search for new opportunities in the higher education system to use the process of developing students' media competence.

The leading trend in the development of the modern system of higher education is the transition to the organization of the learning process based on the joint development activities of all its participants, i.e. educational collaboration. If we turn to the standards of higher education, then the Federal State Educational Standards of Higher Education (FSES HE) require a competency-based approach to teaching disciplines, presenting new requirements for the structure, conditions of implementation and criteria for the effectiveness of students mastering the work program of the discipline (WPD). Each standard contains universal and general professional competencies, in the content of which there is also work with the field of media. All this testifies to a shift in the educational paradigm towards global progress.

Primary school teachers are one of the most important specialists in the field of education, in the framework of which they build successful activities and, in general, the life of the future generation. The life perspective of the student and the construction of the whole society will depend on how they master the curriculum of the chosen direction, what theoretical knowledge, competencies, and skills they will acquire as part of their studies at a pedagogical university. Also, primary school age is the most important for the development of mental actions and operations, during this period verbal-logical thinking, voluntary attention, mental activity are especially active, interest in educational activity is formed, the adoption of rules of behavior, the personality's social orientation begins to take shape, as well as the main the authority at this age is the teacher (Vygotsky L.S., 2005) The presence of a teacher of primary grades of media competence will allow him to organize an interesting, dynamic, informative process of teaching younger students. In addition, this professional quality will allow the 
teacher to provide elementary knowledge in the field of media necessary for younger students at this age. This is due to the fact that the Ministry of Education of the Russian Federation has prepared amendments to the new standards of primary education, which indicate that, for example, in the framework of the subject "Technology", younger students will study graphic, multimedia editors, etc. Within the framework of the National, the project "Education" established the creation of a modern and safe digital educational environment that provides high quality and accessibility of education of all types and levels (Matyushkina M. D., 2012). Therefore, an elementary school teacher can implement the work of primary school students in the field of media in the areas indicated in Figure 1.

Figure 1

The direction of the primary school teacher in the field of media

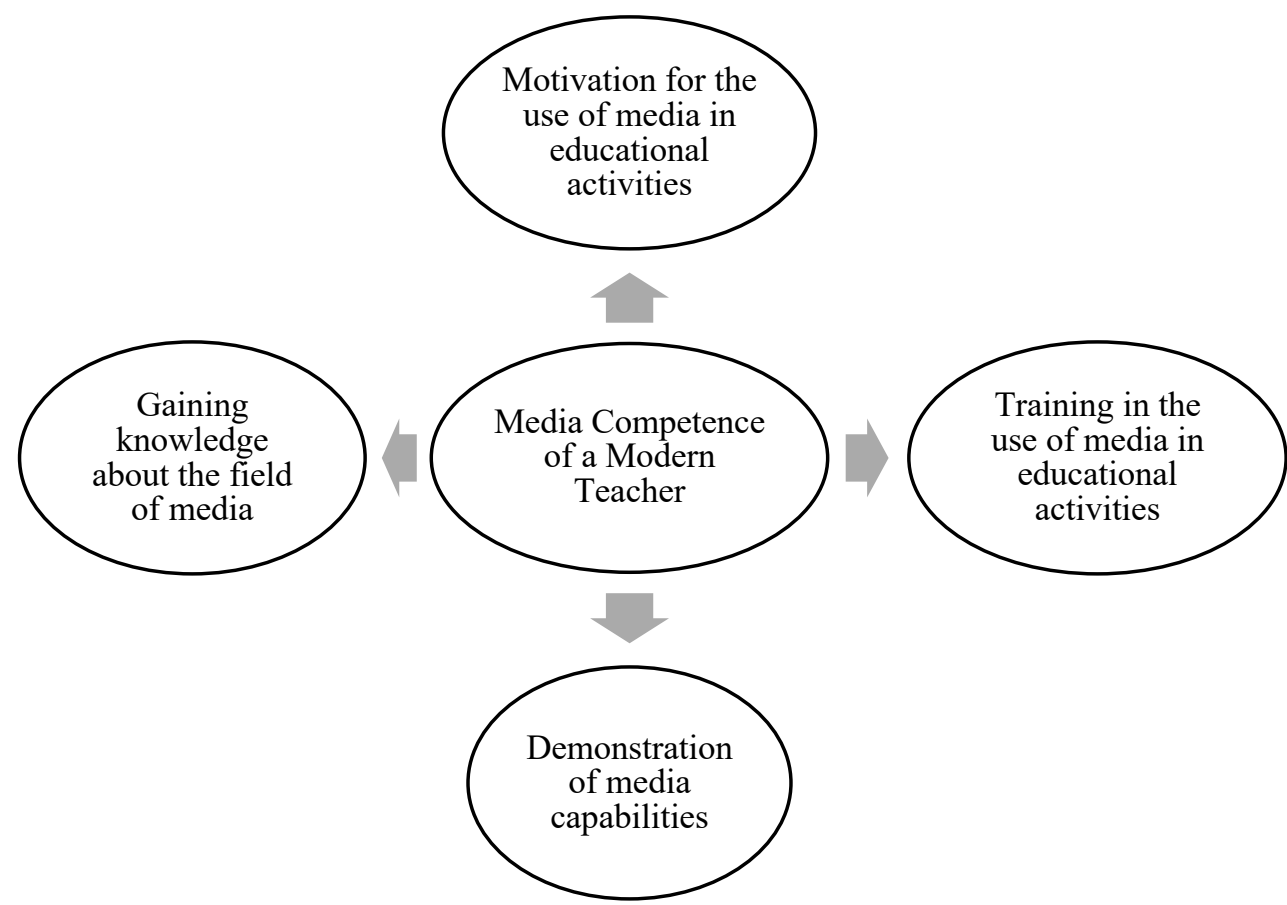

Based on the foregoing, we consider it important to work on the development of media competence in the process of teaching bachelor students in the following areas: "Pedagogical education", "Pedagogical education (with two training profiles)".

However, the question arises of how and within which disciplines to organize this activity.

In this regard, we should turn to the concept of "information-educational environment" (IEE), which means a combination of interconnected information, operational, material components necessary for information support of the educational process based on the use of a complex of data transmission tools, information resources, and hardware and software . In the Order of the Ministry of Education and Science of Russia dated October 6, 2009 No. 373, the structural components of the IEE of an educational institution are indicated, among which we note technological means, forms of information interaction, competence of participants in the educational process in solving educational, cognitive and professional tasks using information and communication technologies (ICT).

Another component of the IEE is the digital educational environment (DEE), the content of which is indicated in the Order of the Ministry of Education of the Russian Federation of December 2, 2019 N 649 "On the approval of the Target Model of the Digital Educational Environment". It is associated with the creation and development of conditions for the implementation of educational programs using e-learning, distance-learning technologies, 
taking into account the functioning of electronic IEE. It follows from this that the development of media competence of students of a pedagogical university is possible by means of IEE.

However, there is a problem of defining relevant aspects in the framework of this development. The teacher can consider the features of working with media in the framework of teaching a particular discipline or give information about the types of media and the features of their use in the lesson in primary school, or consider the interaction of the primary school teacher with all participants in the educational process in the field of media, etc. There are a large number of directions in the teacher's work with students, you can work in detail on the field of media in practice (using media, organizing media communication, selecting methods and techniques for building media competence in elementary school students) or analyze existing research (theoretical aspects of media education, the ratio of media work in various concepts). But this amount of work cannot be included in the content of the WPD, as there are sections and topics that are already planned as lectures, practical and laboratory exercises. In this case, the teacher can introduce only certain components into the practice of his work aimed at developing media competence. Therefore, it is necessary to determine from all their diversity those relevant for the development of media competencies, the work with which is necessary for the effective work of a teacher in primary school.

\section{Methodology}

The main goal of the work was to identify those thematic groups in the field of media competence that meet the requirements of modern society, can be adapted to work with elementary school students to form their elementary ways of acting in the media environment. In addition, it is important to understand exactly which forms, methods and means are relevant for the modern teacher, and which topics will allow them to use their knowledge in primary education, taking into account the changing conditions of the educational process, for example, in a pandemic. The choice of the relevant components of the study was based on an analysis of the content of the regulatory framework of higher and primary education, as well as basic research in the field of media competence development among students. The survey was determined to be the most objective method of research. To this end, a survey was developed for students of the faculty of training teachers of primary school graduates. The choice of the group of respondents is due to the fact that this category of students has already passed pedagogical practice as a primary school teacher in educational organizations. These students can objectively determine the components of media competencies that need to be developed by a future specialist in primary education.

When constructing the content of the survey, it was decided to use the ranking method. The choice of the survey as a method for determining the relevant components of the development of media competence is related to the fact that it is a data collection in which the researcher can obtain information directly from a specific group of students in such a way that reliable conclusions can be drawn based on their answers.

So, the answer options that were highlighted by students of 4-5 courses, taking into account their distribution by importance, are presented below:

1. The rules of communication on the Internet (the organization of indirect communication, the rules of speech ethics in a social network, e-mail, etc.).

2. The possibilities of using media in the process of teaching elementary school students (types of media, methods for including them in the content of the lesson in elementary school).

3. Ways to work with information using media (search, selection, grouping and other information).

4. Theoretical foundations of the field of media (familiarity with the basic concepts of the field of media).

5. Critical attitude to the field of media (the definition of malicious sites and sites that have negative informational and psychological effects). 
6. The impact of the media field on a primary school student (the amount of time allotted to work with media, age characteristics of primary school students).

To confirm the objectivity of the components identified by the students, we used methods of quality analysis, namely, the assessment of experts. Since the experts should be a group, which includes specialists who are directly related to the research topic and are competent in this area, the content of the survey results was presented to teachers and methodologists in the field of primary education and the information and educational environment.

\section{Results}

Since in the first place students put the rules of communication on the Internet $(40 \%)$, in the second the possibility of using media in the process of teaching younger students (34\%), in the third working with information using media (16\%), and the remaining responses are distributed among other items (10\%) then one of the disciplines in which you can develop the first component is the discipline of humanitarian cycle, namely, "Methods of teaching the Russian language and literary reading in elementary school." We determined this science as the most effective for working with the information and educational environment in the process of implementing the research results due to the fact that communication carried out on the Internet in social networks, messenger applications, special educational systems should be carried out correctly. And in order for this to happen, appropriate training is necessary, which can be implemented within the framework of this discipline.

Thus, the results obtained prove that the future primary school teacher must not only learn how to interact with the participants of the educational process in the virtual space, but also in modern realities to teach younger students this work. The learning and development process cannot be static, therefore, transformations must also occur in the methodology. The level of education of a teacher in the field of media to a large extent determines the success of the process of forming the system of necessary knowledge and skills in primary school students.

\section{Discussion}

So, the educational environment is a mobile system that needs to be developed, maintained, and adapted to the modern realities of life. Today, significant changes are taking place within the framework of professional pedagogical activity: new forms of training are being introduced, standards are being transformed at all levels of education, elements of distance learning are being used, and active use of new teaching aids and technologies is being carried out.

All these changes are justified by scientific progress, the development of society and the requirements of the social order of the state. Therefore, it is impossible to work with students in traditional obsolete ways, to use non-relevant knowledge. In this regard, the organization of the process of developing their competence plays an important role in the future professional activities of primary school teachers. Orientation of education to the interests of society contributes to the successful activities of future specialists, as well as society as a whole

\section{Conclusions}

We suggest designing media competencies for the selected component in the process of mastering the discipline "Methods of teaching the Russian language and literary reading in elementary school" using IEE tools. Educational resources of IEE are allocated methodological, didactic and regulatory support (Andreev A.A., 2000).

From the point of view of methodological support of IEE, we propose to include work with media competence in the framework of lecture and practical classes. For example, in the framework of the methodology for studying linguistic concepts or literary works, as well as in the design of Russian language lessons and literary reading, explain to students what possibilities of media they can use with younger students. In addition, it is important to 
voice the order and algorithm of interaction with participants in the educational process when organizing distance learning (media communication rules).

From the point of view of didactic support of IEE, it is necessary to develop educational and practical manuals within the framework of a discipline in which to specify the features of working with media in the framework of lessons in elementary school and a glossary with basic concepts from the field of media.

From the point of view of normative support for IEE, we propose to compile a database of documents that students can use when designing a lesson in Russian, literary reading, or organizing the learning process in primary school as a whole (including in the remote format).

\section{Bibliographic references}

Andreev A.A. (2000) Theoretical and methodological approach to the design and implementation of network education. Internet technologies in open education. Seminar materials. M .: MESI, P.12-14.

Chelysheva I.V. (2006) Theory and History of Russian Media Education. Taganrog: Publishing house of Kuchma, $206 \mathrm{p}$.

Federal state educational standards of higher education. Retrieved from: http://fgosvo.ru

Federal State Unitary Enterprise "Information Telegraph Agency of Russia (ITAR-TASS)" Retrieved from: https://tass.ru

Fedorov A.V., Onkovich A.V., Levitskaya A.A. (2013) Trends in the development of secular and theological media education in Russia and abroad. Taganrog: Publishing house of Taganrog. stateped. Institute of A.P. Chekhov, $308 \mathrm{p}$.

loksha E. A. Modern trends in the development of education in the world Retrieved from: http://ext.spb.ru/2011-03-29-09-03-14/75-correctional/12252Sovremennye_tendentsii_razvitiya_obrazovaniya_v_mire.html

Matyushkina M. D. (2012) Methods of pedagogical research: a textbook. SPB, 178 p.

Order of the Ministry of Education and Science of the Russian Federation of October 6, 2009 N 373 "On approval and enforcement of the federal state educational standard of primary general education" Retrieved from: https://base.garant.ru/197127/

Order of the Ministry of Education of the Russian Federation of December 2, 2019 N 649 "On approval of the Target Model of the Digital Educational Environment" Retrieved from: https://www.garant.ru/products/ipo/prime/doc/73235976/

The national project "Education" Retrieved from: https://edu.gov.ru/national-project

The order of the Government of the Russian Federation of October 20, 2010 N 1815-r "On the state program of the Russian Federation "Information Society (2011-2020)" Retrieved from: https://base.garant.ru/199708/

Usov Yu.N. (2010) Media education. The program for students of grades 10-11 of a comprehensive school. Fundamentals of screen culture. The cycle of programs. M., $45 \mathrm{p}$.

Vygotsky L.S. (2005) Psychology of human development. M .: Publishing house Smysl; Eksmo, 1136 p.

Zaznobina L.S. (1999) Media Education Integrated with Basic. M.: Publishing House of the Southern District of Moscow Education, 173 p. 